\title{
Juridic Review of Legal Protection towards Teachers as Educators
}

\author{
Denny Zahuri ${ }^{1}$, Evita Isretno Israhadi ${ }^{2}$ \\ Student at Doctoral of Law, Universitas Borobudur Jakarta \\ \{dennyunborr@gmail.com ${ }^{1}$, evita_isretno@borobudur.ac.id $\left.{ }^{2}\right\}$
}

\begin{abstract}
The preamble to the 1945 Constitution of the Republic of Indonesia has mandated to educate the nation's life. The government embodies the intellectual life of the nation by pursuing and implementing a national education system that aims to improve the quality of Indonesian people. The quality of Indonesian people is produced through the provision of quality education by professional educators. Teachers as professional educators have a very strategic function, role, and position. However, in carrying out their duties, teachers are often reported to have violated children's protection rights when giving disciplinary violations against students. Many teachers have been caught up in the law as a result of being accused or suspected of violating Law Number 35 of 2014 concerning Child Protection. This of course will have an impact on efforts to improve the quality of Indonesian people, which is the goal of national education. Therefore, to support the strategic function and role of teachers as educators, legal protection efforts need to be made. This is intended to provide a sense of security and comfort for teachers in carrying out their duties and profession. Constitutionally, teachers as citizens have the right to be protected. The provisions for the legal protection of teachers in Indonesia are generally regulated in Law Number 20 of 2003 concerning the National Education System, Law Number 14 of 2005 concerning Teachers and Lecturers, Government Regulation Number 74 of 2008 concerning Teachers, and specifically regulated in a Ministerial Regulation Education and Education and Culture Number 10 of 2017 concerning Protection of Educators and Education Personnel. This study aims to determine the juridical review of the protection of teachers as educators. This research is normative legal research using a statutory and conceptual approach.
\end{abstract}

Keywords: Legal Protection; Teacher; Educator

\section{Introduction}

The preamble to the 1945 Constitution of the Republic of Indonesia mandates the Government of the Republic of Indonesia to protect the entire Indonesian nation and all Indonesian blood and to promote public welfare, educate the nation's life, and participate in implementing world order based on independence, eternal peace, and social justice. The government embodies the intellectual life of the nation by endeavoring and implementing a national education system that increases faith and devotion to God Almighty, as well as noble morals. One of the goals of national education is to improve the quality of Indonesian people. 
The quality of Indonesian people is produced through the provision of quality education by professional educators. Therefore, teachers as professional educators have a very strategic function, role, and position. Teachers as professionals have a vision for the realization of the implementation of learning under professional principles to fulfill the equal rights of every citizen in obtaining a quality education. Teachers have a very vital position because they are agents of change, meaning the agents or the main figures who have the most influence in improving the quality and quality of education in Indonesia. If the quality and quality of education in Indonesia is very good, it will produce future generations of the nation with good quality in terms of religion, morals, and science [1].

According to the old view, the teacher is a human figure who should be dignified and imitated. Dignified in the sense that all his words can be trusted, imitated means that all of his behavior must be able to be an example or an example for society. In a simple sense, a teacher is a person who provides knowledge to students. Teachers in the view of society are people who carry out education in certain places, both formal and non-formal educational institutions. However, over time, there has been a shift in values in society. At this time, teachers often reported violating children's protection rights when giving sanctions for disciplinary violations against students. The world of education is marked by cases of criminalization, abuse, and acts of violence against teachers. The euphoria of Human Rights (HAM) and violations of children's rights seem to be a nightmare for teachers in carrying out their duties. Many teachers have been caught up in the law as a result of being accused or suspected of violating Law Number 35 of 2014 concerning Child Protection.

As a result, teachers as educators seem to face a dilemma, on the other hand, they have to uphold school discipline and order, while on the other hand, they are worried that they will be criminalized by parents or child advocates for accusations of violence against children. The impact of this dilemma, ultimately the teacher becomes less assertive towards students who are naughty or violate school rules. The naughty students are left alone, instead of the teacher getting into legal trouble. This of course will have an impact on efforts to improve the quality of Indonesian people, which is the goal of national education.

Based on the foregoing, the government with support from teacher professional organizations issued Permendikbud Number 10 of 2017 to protect Teachers and Education Personnel. Article 2 paragraph 1 states that "Protection is an effort to protect educators and education personnel who face problems related to the implementation of their duties." And in paragraph 2 it is stated that "Protection, as referred to in paragraph (1), includes the protection of: (a) law, (b) profession, (c) occupational safety and health; and/or (d) intellectual property rights". With this rule, teachers are no longer haunted by criminalization for their actions to discipline students. Even so, teachers also need to improve their pedagogical competencies, and personality competencies, and master the developmental psychology of students. Based on this background, legal protection for teachers as educators is important. It is important to research it more focused and deeply from the perspective of legal science in the form of a juridical review of legal protection for teachers as educators. Assessing the extent of the juridical review of legal protection for teachers as educators based on the point of view of the laws and regulations relevant to this research.

\section{Research Problem}

Based on the background described above, the formulation of this research problem can be formulated as follows:

"What is the juridical review of legal protection for teachers as educators?" 


\section{Research Method}

This research is normative legal research. Normative research is often called doctrinal research, which is research whose object of study is legal documents and library materials [2]. The approach used is the statute approach and the conceptual approach [3]. Approach the law, because what will be examined are various legal rules that become the focus as well as the central theme of a study. The conceptual approach is intended to analyze legal materials so that the meaning contained in legal terms can be seen. This was done as an attempt to obtain new meanings contained in the terms studied or to test these legal terms in theory and practice.

\section{Results and Discussion}

\subsection{Description of Teacher}

A teacher is an old profession in the world. Teaching work has been occupied by him for a long time. The development of the teaching profession is in line with the development of society. Etymologically, the term guru comes from the Indian language, which means people who teach about deliverance from suffering [4]. In Sanskrit, teacher means someone who is respected, a figure who has no gaps and must not have mistaken. Teachers are not only educators and teachers, but also carry out the mission of being religious, apart from being wise they also master science and carry out moral and religious values. Rabinranath Tagore (19861941), used the term Shanti Niketan or peaceful house for teachers to practice their noble duties in building spiritual intelligence for Indian children (spiritual intelligence) [5].

The understanding of the teacher then gets wider, not only limited in the scientific context of spiritual intelligence and intellectual intelligence, but also regarding bodily-kinesthetic intelligence, such as dance teachers, sports teachers, and music teachers. According to psychologist Howard Garber, all intelligence is essentially also part of multiple intelligence [6]. Thus, teachers can be interpreted as people whose duties are related to efforts to educate the nation's life in all its aspects, both spiritual and emotional, intellectual, physical, and other aspects.

According to the old view, the teacher is a human figure who should be dignified and imitated. Dignified in the sense that all his words can be believed, imitated means that all of his behavior must be able to be an example or an example for society [7]. In a simple sense, a teacher is a person who provides knowledge to students. In the view of society, teachers are people who carry out education in certain places, both formal and non-formal educational institutions [8].Lexically the teacher is defined as "a person whose job or livelihood teaches". In a simple sense, a teacher is a person who provides knowledge to students [9].

The definition of teachers according to Law Number 14 of 2005 concerning Teachers and Lecturers, Article 1, number 1, what is meant by "Teachers are professional educators with the main task of educating, teaching, guiding, directing, training, assessing, and evaluating students in children's education. Early childhood formal education, basic education, and secondary education".

This understanding is similar to that contained in Government Regulation Number 74 of 2008 concerning Teachers, Article 1 that what is meant by "Teachers are professional educators with the main task of educating, teaching, guiding, directing, training, assessing, and evaluating students in the education of children of age. Early formal education, basic education, and secondary education". 
Then according to Law Number 20 of 2002 concerning the National Education System, Article 1 point 6 , what is meant by "Educators are educational staff who are qualified as teachers, lecturers, counselors, tutors, lecturers, tutors, instructors, facilitators, and other names according to their specialty, as well as participating in organizing education".

Furthermore, according to the Regulation of the Minister of Education and Education and Culture Number 10 of 2017 concerning Protection of Educators and Education Personnel, Article 1 point 1 , what is meant by "Educators are teachers, tutors, instructors, facilitators, and technical resource persons".

\subsection{Position, Function and Purpose}

In their position, teachers have a position as professional staff at the levels of basic education, secondary education, and early childhood education in the formal education pathway which is appointed by statutory regulations. [10] The recognition of the teacher's position as a professional is evidenced by an educator certificate. [11] The position of teachers as professionals serves to increase the dignity and role of teachers as agents of learning to improve the quality of national education [12].

The position of teachers as professionals aims to implement the national education system and realize the goals of national education, namely the development of the potential of students to become human beings who believe and fear God Almighty, have a noble character, are healthy, knowledgeable, capable, creative, independent, and become citizens. a democratic and responsible country [13].

\subsection{Teacher's Legal Protection}

Whereas the 1945 Constitution of the Republic of Indonesia, Article 1 paragraph (3) states: "The State of Indonesia is the State of Law". This provision means that the Unitary State of the Republic of Indonesia is a country that in administering government is based on legal principles. The 1945 Constitution of the Republic of Indonesia, Article 28G paragraph (1), states that every person has the right to protection of himself, family, honor, dignity, and property under his control, as well as to a sense of security and protection from the threat of fear to do or not to do something that is a human right. This provision can be interpreted that the government or state is obliged to protect its citizens, including teachers.

In this context, all teachers must be legally protected from any anomalies or arbitrary actions that may or have the potential to happen to them from irresponsible parties. Legal protection referred to includes protection arising from actions of students, parents of students, society, bureaucracy, or other parties. Legal protection was created as a means or instrument to regulate the rights and obligations of legal subjects. Besides, the law also functions as an instrument of protection for legal subjects. One of the most important functions of law is the achievement of order in human life in society [14].

According to Satjipto Raharjo, the function of law is to protect a person's interests by allocating some power to him to act in this interest. The allocation of power is carried out in a measured manner, in the sense that its breadth and depth are determined [15]. Protection is defined as an act of guaranteeing, or security, peace, welfare, and peace from the protector to the one who is protected against all the dangers or risks that threaten him. Protecting is done through legal protection.

Legal protection is an effort by the authorities to provide guarantees and conveniences in such a way so that every citizen or all citizen can actualize their rights and obligations 
optimally in an orderly and calm manner [16]. Concerning the legal protection of teachers in Indonesia, this provision is contained in Law Number 20 of 2003 concerning the National Education System, Article 40 paragraph (1) letter d, states that "educators and education personnel are entitled to legal protection in carrying out their duties and rights to intellectual property results".

Other provisions are contained in Law Number 14 of 2005 concerning Teachers and Lecturers, Article 39, which states that "The government, local governments, communities, professional organizations and/or educational units are obliged to protect teachers in carrying out their duties". One of the protections referred to is legal protection. This legal protection includes legal protection against acts of violence, threats, discriminatory treatment, intimidation, or unfair treatment on the part of students, parents of students, society, bureaucracy, or other parties [17].

Furthermore, it is regulated in Government Regulation Number 74 of 2008 concerning Teachers, Article 40 paragraph (1), which states that "Teachers are entitled to protection in carrying out their duties in the form of a sense of security and safety guarantees from the Government, Local Government, educational units, Teacher Professional Organizations, and/or the Community under their respective authorities".

A sense of security and a guarantee of safety in carrying out tasks is obtained by the teacher through protection, one of which is legal protection [18]. Teachers have the right to legal protection from acts of violence, threats, discriminatory treatment, intimidation, or unfair treatment on the part of students, parents of students, society, bureaucracy, or other parties [19]. In particular, teacher legal protection is regulated in the Regulation of the Minister of Education and Education and Culture Number 10 of 2017 concerning Protection for Educators and Education Personnel, Article 2 paragraph (1), (2) and (3), which reads:

a. Protection is an effort to protect educators and education personnel who face problems related to the implementation of their duties.

b. Protection as referred to in paragraph (1) includes protection:

1. Law;

2. Profession;

3. Occupational health and safety; and/or

4. Intellectual property rights.

c. Legal protection as referred to in paragraph (2) letter a includes protection for:

1. Violence;

2. Threat;

3. Discriminatory treatment;

4. Intimidation; and/or

5. Unfair treatment, on the part of students, parents of students, the community, bureaucracy, and/or other parties related to the implementation of duties as educators and education personnel.

The protection referred to in Article 2 above is the obligation of the Government; Regional Government under their authority; Education units; Professional Organization; and/or Society. Protection by the government is carried out by the Ministry or other ministries that carry out government affairs in the field of education [20].

The protection provided by the Ministry is carried out in the form of non-litigation advocacy. Non-litigation advocacy is the facilitation of case settlement out of court in the form of legal consultation, mediation, and/or fulfillment and/or restoration of the rights of Educators and Education Personnel. Legal consultation can be in the form of providing suggestions or opinions for dispute or dispute resolution. Mediation is a way of resolving 
disputes through the negotiation process to obtain agreement from the parties. Fulfillment and/or restoration of the rights of Educators and Education Personnel in the form of assistance to Educators and Education Personnel to obtain legal counsel in solving cases through criminal, civil, or state administrative proceedings, or the fulfillment of compensation for Educators and Education Personnel [21].

The science of legal consultation is to provide a legal opinion requested by the client or the disputing parties, and then the dispute resolution decision is taken by the parties themselves based on the opinion given [22]. Consultation is also a meeting of two or more parties to discuss issues that are considered important so that they can find solutions together.

Meanwhile, mediation is an alternative dispute resolution (APS). Mediation is a way of resolving disputes outside the court through negotiations that involve parties when they are neutral (non-intervening) and impartial to the disputing parties and their presence is accepted by the disputing parties [23]. In line with what Gary Goodpaster put forward, defining mediation is a process of negotiating a problem-solving in which an impartial and neutral outside party works with the disputing parties to help them obtain a satisfactory agreement [24].

In this case, it is usually assisted by a mediator as a third party. Furthermore, this Ministerial Regulation also explains that in implementing protection, the Ministry can coordinate with Local Governments, Education Units, Professional Organizations, Communities, and/or other related parties [25]. Meanwhile, protection by the Regional Government, Education Units, Professional Organizations, and Communities under their respective authorities are obliged to provide resources and establish mechanisms for providing protection, by the provisions of laws and regulations [26].

Based on the explanation above, the existence of legal protection for teachers as primary educators in the form of Regulation of the Minister of Education and Culture Number 10 of 2017 concerning Protection for Educators and Education Personnel is a form of government efforts to protect teachers and education personnel in carrying out their duties. The protection obtained by teachers and education personnel includes legal protection, profession, occupational safety, and health and intellectual property rights. With this legal provision, it will provide more guarantee for legal protection for teachers as educators who face problems related to the implementation of their duties.

\section{Conclusion and Suggestion}

\subsection{Conclusion}

Teachers as professional educators have a very strategic function, role, and position. Disciplinary action performed by teachers, which in the past was considered mediocre, has now been shifted and is considered to have violated human rights so that many teachers are caught in the law due to being accused or suspected of violating Law Number 35 of 2014 concerning Child Protection. The rise of various cases that have befallen teachers in carrying out their professional duties is one proof that legal protection for the teaching profession has not been effective. This of course will have an impact on efforts to improve the quality of Indonesian people, which is the goal of national education. Therefore, it is necessary to take legal protection measures. Constitutionally, teachers as citizens have the right to be protected.

In particular, the legal protection of teachers is now regulated by the Regulation of the Minister of Education and Culture Number 10 of 2017 concerning Protection of Educators and 
Education Personnel. In this regulation, the protection obtained by teachers and education personnel includes legal protection, profession, occupational safety, and health and intellectual property rights. With this legal provision, it will provide more guarantee for legal protection for teachers as educators who encounter problems related to the implementation of their duties. Also, it provides a sense of security and comfort for teachers in carrying out their duties as a form of just legal certainty.

\subsection{Suggestion}

a. The need for more effective or surgical socialization of the Permendikbud. This can be done either by the government, teacher professional organizations, or groups that care about education. The role of the mass media is also needed to socialize the Permendikbud so that it is quickly recognized by relevant parties, such as teachers, parents, legal officials, and various other stakeholders.

b. There is a need for political will from the government towards the implementation of the Permendikbud because there are times when a rule is so good on paper, but in its implementation, it is not optimal because of the government's low political will.

c. Teachers must be encouraged to read the various regulations concerning their profession to become literate and law-aware teachers.

\section{References}

[1] Matnuh, Harpani.: Perlindungan Hukum Profesionalisme Guru. Jurnal Pendidikan Kewarganegaraan. Volume 7, Nomor 2. (November 2017)

[2] Soejono dan H. Abdurahman.: Metode Penelitian Hukum. Rineka Cipta Jakarta (2003)

[3] Marzuki, Peter Mahmud.: Penelitian Hukum. Edisi Revisi, Prenada Kencana, Jakarta (2014)

[4] Shambuan,: Republika. 25 November 1997.

[5] Suparlan.: Menjadi Guru Efektif. Hikayat Publishing, Jogjakarta (2001) Mencerdaskan Kehidupan Bangsa, Dari Konsepsi Sampai Implementasi. Grafindo Persada, Jakarta (2002)

[6] Suparlan.: Menjadi Guru Efektif. Hikayat Publishing, Jogjakarta (2001) Mencerdaskan Kehidupan Bangsa, Dari Konsepsi Sampai Implementasi. Grafindo Persada, Jakarta (2002)

[7] Jumali, M. dkk.: Landasan Pandidikan. MUP, Surakarta (2008)

[8] Kurniasih, Imas, Berlin Sani.: Sukses Uji Kompetensi Guru (UKG). p. 6. Kata Pena, Surabaya (2015)

[9] Akhyak.: Profil Pendidikan Sukses. Elkaf, Surabaya (2005)

[10] Undang-Undang Nomor 14 Tahun 2005 tentang Guru dan Dosen.

[11] Undang-Undang Nomor 14 Tahun 2005 tentang Guru dan Dosen.

[12] Undang-Undang Nomor 14 Tahun 2005 tentang Guru dan Dosen.

[13] Undang-Undang Nomor 14 Tahun 2005 tentang Guru dan Dosen.

[14] Kusumaatmadja, Mochtar.: Pengantar Ilmu Hukum. Alumni, Bandung (2009)

[15] Undang-Undang Nomor 20 Tahun 2003 tentang Sistem Pendidikan Nasional

[16] Undang-Undang Nomor 20 Tahun 2003 tentang Sistem Pendidikan Nasional

[17] Undang-Undang Nomor 14 Tahun 2005 tentang Guru dan Dosen.

[18] Peraturan Pemerintah Nomor 74 Tahun 2008 tentang Guru 
[19] Peraturan Pemerintah Nomor 74 Tahun 2008 tentang Guru

[20] Peraturan Menteri Pendidikan dan Pendidikan dan Kebudayaan Nomor 10 Tahun 2017 tentang Perlindungan Bagi Pendidik dan Tenaga Kependidikan.

[21] Peraturan Menteri Pendidikan dan Pendidikan dan Kebudayaan Nomor 10 Tahun 2017 tentang Perlindungan Bagi Pendidik dan Tenaga Kependidikan.

[23] Hadimulyo.: Mempertimbangkan ADR, Kajian Alternatif Penyelesaian Sengketa di Luar Pengadilan. ELSAM, Jakarta (1997)

[24] Umam, Khotibul.: Penyelesaian Sengketa Di Luar Pengadilan. Pustaka Yustisia, Yogyakarta (2010)

[25] Peraturan Menteri Pendidikan dan Pendidikan dan Kebudayaan Nomor 10 Tahun 2017 tentang Perlindungan Bagi Pendidik dan Tenaga Kependidikan.

[26] Peraturan Menteri Pendidikan dan Pendidikan dan Kebudayaan Nomor 10 Tahun 2017 tentang Perlindungan Bagi Pendidik dan Tenaga Kependidikan. 